\title{
A KÖZIGAZGATÁS ÉRTÉKKÖTÖTTSÉGE AZ ALKOTMÁNYOS JOGÁLLAMBAN
}

\author{
(The Influence of Values on Public Administration \\ in a Constitutional State)
}

ÁDÁM ANTAL

\section{Bevezető megjegyzések}

Tanulmányomban arra törekszem, hogy körvonalazzam a közigazgatás értékkötőttségének gyorsuló kiterjedését és egyéb megnyilvánulásait az európai kontinentális alkotmányos jogállamban. E feladat elvégzéséhez először felidézem az alkotmányos jogállamnak azokat az újszerủ vonásait, amelyek megkülönböztetik a jogállam korábbi (vagyis a liberális és a szociális) fejlödési szakaszaitól. Ezt követỏen vázolom az értékek általános jellemzőit, valamint az alkotmányi értékek mibenlétét és föbb csoportjainak hatását az állami szervek müködésére. Mivel a közigazgatás értékkőtőtttségére jelentős befolyást gyakorolnak azok az újszerú jogrétegek, amelyek a fejlett országokban az utóbbi évtizedekben alakultak ki, külön fejezetben rendszerezem ezeket. A közigazgatás értékkötöttségében korszakunkban is fontos szerepre hivatottak a kulönbözö természetü - vallási, szekularizált, jogszabályi rangra emelt erkőlcsi normák, ezért írásom záró fejezetében a jogrendszer erkőlcsiesedésének általános problémáit és a közigazgatási erkölcsi normák kidolgozásának időszerŭ kérdéseit igyekszem áttekinteni. Mindezek révén érveket és bizonyítékokat szeretnék felsorakoztatni annak a megállapításnak az alátámasztására, amely szerint egyrészt látványosan szaporodnak azoknak a normáknak a fajtái, amelyeket a közigazgatásnak tiszteletben kell tartania, másrészt nagymértékben gyarapodnak, változnak, kiegészuilnek azok az értékek, amelyeket a közigazgatásnak védenie, szolgálnia és alkalmaznia kell.

\section{A liberális jogállamtól az alkotmányos jogállamig}

1) A liberális jogállam a felvilágosodás eszméiból kiindulva a modernitás jegyében a szulletési előjogok és az abból fakadó rendi tagozódás megszüntetésének, a polgári társadalom és a politikai állam elválasztásának, az államhatalmi ágak elkülönítésének, a személyi szabadság és a tờrvény elötti formális egyenlöség garantálásának, a magántulajdon, a vállalkozás, a piaci verseny szabadságának, a szabad versenyen nyugvó piacgazdaság automatikus ơnszabályozásának jelszavát túzte zászlajára. Abszolút bizalommal, mély hittel és optimista reménységgel tekintett a nemzetgazdaságnak, a társadalomnak, az emberiségnek a tudományos müszaki fejlödésen és az emberi szabadságon nyugvó töretlen és szinte határtalan haladására. 
Ez a felfogás a népképviselet és a közakarat jelentőségének hangsúlyozásával piedesztálra helyezte, és a jelzett eszmekörben rendkivull kiterjedt mérlegelési szabadsággal ruházta fel a törvényhozó hatalmat. A jogszabályok rendszerében a törvény volt a legtekintélyesebb jogforrás. Törvényhez kötötté vált a végrehajtó hatalom és a közigazgatás. Törvény volt az elsődleges mércéje és határa az emberi és állampolgári jogoknak is.

A modernitás több, mint kétszáz éves történetének, remélt és nem várt tapasztalatainak kritikus vizsgálata alapján nem csekély csalódottsággal, kiábrándultsággal és a további jövő iránti kétellyel, bizonytalansággal állapitható meg, hogy a jelzett ártatlan hittel és bizalommal övezett szabadpiac láthatatlan ơnvezérlésének szerepét bámulatos sikerek, kegyetlen megrázkódtatások, súlyos válságok után számos újszerủ körülménytől (így különösen a hadigazdálkodás, a nemzetgazdaságok tudományos, múszaki, jóléti és szociális versengése, a különböző régiók fejlettségi szinvonalában meglévő különbözöségek kiegyenlítésére irányuló állami és államközi eröfeszítés, a nemzetgazdaságok összetevőinek összehangolása, illetve integrálása által) is indíttatva, jelentös mértékben az állami tervezés, befolyásolás, ösztönzés, szervezés, fejlesztés egészítette ki, vagy váltotta fel. Az éjjeli ör szerepére kárhoztatott liberális jogállam nemcsak a már megbukott totalitárius, autoritárius rendszerekben tủnt el, hanem a polgári szabad szervezödésủ, nyílt társadalmakban is jelentősen változott.

Föleg a hadigazdálkodás szükségletei, a szociális feszilltségek enyhítésének kényszere, az országok és államok kőzötti sokoldalú versengés váltották ki a szociális és a jóléti jogállam impozáns fejlesztési, gondoskodási törekvéseit, valamint a magánszférába, különösen a magánjogi és a munkajogi viszonyokba való állami beavatkozás markáns megnyilvánulásait. Kơrulhatároltabbak lettek a gazdasági versenyszabadság lehetőségei. A sokrétú állami ösztönzés, befolyásolás, korlátozás és más beavatkozás folytán lényegesen változott a szabad versenyen nyugvó piacgazdaság önszabályozó mechanizmusa. Az elkülönült társadalom és az azt alkotó csoportok, rétegek, közösségek bővưlö és nővekvő ellátási, szolgáltatási elvárásokat, igényeket támasztanak az állammal szemben. Az államhatalmat gyakorló állami szervek társadalmi elfogadottsága nagymértékben függ e társadalmi követelések kielégítésének színvonalától.

A káprázatos tudományos, múszaki fejlesztéssel, az ơkológiai egyensúly felbomlásával, az élővilág súlyos pusztulásának fenyegetésével szemben kategorikus imperatívusszá vált az ésszerủ fejlesztés, a fenntartható fejlődés kővetelménye. Sőt már az is egyre világosabbá válik, hogy az infrastrukturális fejlesztés terhét, a gazdálkodás ösztönzését és korlátozását, a szociális feszültségek enyhítését és a közjólét fokozását vállaló állam terhei, szerepe és felelössége mellett jelentőségüket, sorrendiségüket tekintve egyre inkább elötérbe kerülnek, és az említett hagyományos funkciókat is megelózik azok a feladatok, amelyek az egyént, a közösséget, a társadalmat és az emberiséget fenyegető apokaliptikus veszélyek, fenyegetések megelözésével, elháritásával, a bekövetkezett és elszenvedett csapások és károk következményeinek helyreállításával, kijavitásával függnek össze. 
2) A liberális és a szociális jogállam jellemzőinek vázlatos felidézése után az alkotmányos jogállam megkülönböztetö jegyeinek összegezését néhány megjegyzés előrebocsátásával kezdem. Nem kizárt, sőt elönyös és gyakori ugyanis, hogy a jogállam jelzett két típusának némely elemei eredeti vagy módosult változatban az alkotmányos jogállamban is megtalálhatók. E jogállami alakzatok bizonyos megnyilvánulását az alkotmányos jogállam mellözi, módosítja, erösíti vagy gyengíti. Emellett az alkotmányos jogállam több lényeges, új sajátosságot visel magán (Ádóm 1997). Hangsúlyozandónak tartom azt is, hogy az ún. tranzíciós államokban, tehát Magyarországon is, a jogállam vázolt típusainak bizonyos elemeit, illetve ezek kapcsolódásait a napirendre került történelmi átmenet egyedülállósága, gyorsított üteme és rendkívüli nehézségei kiegészítik, módosítják, erősítik vagy gyengitik. Korszakunk magyar közigazgatásának jellemzői részben a hazai hagyományokban gyökereznek, másrészt a politikai, gazdasági, társadalmi változások átmenetiségéből és a földkerekségre kiterjedő globalizáció áramlataiból, valamint az európai integrációs folyamatok egységesítő hatásaiból fakadnak.

a) Az alkotmányos jogállam általános jellemzöi között elsőként említhetjük a törvények széles körü kettös, mégpe dig nemzetközi jogi és alaptörvényi meghatározottságát. Ennek következtében a liberális jogállami viszonyokhoz képest élesen rögzitetté váltak a törvényalkotás tárgyi határai, és egyre erősebbek lettek tartalmi követelményei.

b) Az alaptörvény részbeni nemzetközi jogi meghatározottságával, az egyetemes jogfejlödés értékirányzataihoz való igazodással, az alkotmánynak a közhatalom korlátozását, a törvényalkotást, az igazságszolgáltatást, a közigazgatást, a politikai intézményeket, a közösségek helyzetét meghatározó szerepével, az egyén és a magánszféra védelmével magyarázható az alkotmánynak és az alkotmányosságnak korábban soha sem tapasztalt szerepe az alkotmányos jogállamban. A hazai alkotmányos jogállami keretek között a közigazgatásnak - vagyis a szük értelemben vett államigazgatásnak, az önkormányzati igazgatásnak, az egyéb állami szervekre bízott, a köztestületi, valamint a szerződéssel civil szervezetekre, alapítványokra, gazdálkodó szervezetekre átruházott közigazgatásnak - olyan törvényességnek kell megfelelnie, amelynek kereteit és tartalmi követelményeit a Magyarországra is kötelezö nemzetközi egyezmények, valamint az emberi és állampolgári alapjogokat, alkotmányi alapelveket, tilalmakat, kötelességeket és egyéb értékeket tartalmazó alaptörvény határozzák meg. E megállapitásból pedig az következik, hogy az alkotmányos jogállam keretei között müködö közigazgatás kiterjedt és folytonosan ápolandó értékrendszerhez kötött.

A nemzeti tradíciók, adottságok és törekvések ellenére a kơzigazgatás szférájában is markánsan jelentkeznek bizonyos problémák, és ezek megoldására vonatkozó törekvések egységesülö trendjei. A régi és az újszerü feladatok, pl. a természeti és müszaki katasztrófák megelózése és elháritása, az idegenforgalom, a turisztika tömegesedése, a bevándorlás, a megengedett és tiltott migráció növekedése, a szociális ellátásra, támogatásra szorulók számának emelkedése, a köz- 
biztonság romlásának anomáliái, a közüzemi és egyéb közszolgáltatások fajtáinak gyarapodása és méretének kiterjedése, valamint a felmerülö egyéb feladatok és nehézségek halaszthatatlanná teszik, hogy minden ország kimunkálja és meghatározza a közigazgatás stratégiai reformkoncepcióit (Bản-Könyves Tóth 1997; Ficzere 1996b; Lőrincz 1994; Verebélyi 1996). A tudományos és müszaki haladás, különösen az elektrotechnika illetve a távközlés újabb vívmányainak hasznosításával párhuzamosan mellözhetetlen, hogy a Kormány és a közigazgatás központi irányitó fórumai mélyítsék a közigazgatás egészét és egyes ágazatait érintő felmérő, elemző, értékeló és következtetéseket megfogalmazó, tehát az olyan koncepcionális munkásságukat, amelynek keretében föleg az összefüggéseket, a lehetóségeket, a megoldási módozatokat feltáró, alátámasztó, tudományos igényü vizsgálódások, érvelések és ajánlások nyernek megfogalmazást az egyoldalú kötelezö utasítások helyett (Ficzere 1996a).

c) A hatalommal való visszaélés megelözése, az alkotmányba foglalt értékeket szolgáló rendelkezések megvalósulásának biztosítása, az esetleges alkotmánysértések megelőzése, feltárása és megszüntetése, a felmerüló alkotmányossági viták elbírálása, mindezek révén az alkotmány hiteles és kötelezó értelmezése, vagyis az alkotmányosság védelme érdekében alakult ki, és válik egyre általónosabb jellemzöjévé az alkotmányos jogállamnak az alkotmánybíráskodás. A szakemberek hosszú idő óta sokoldalúan vizsgálták már, és az országok eltérö adottságait szem elött tartva sokszinúen mutatták be az alkotmánybíráskodást kiváltó körülményeket. E tablón az elöidézó okok szempontjából is sajátos helyet foglalnak el az amerikai szövetségi rendes bíróságok által közel 200 éve az eseti rendes bíráskodás keretében gyakorolt alkotmányossági normakontroll kialakulását kiváltó és fejlódését befolyásoló körülmények (Cappeletti-Cohen 1995; Mcloskey 1995). Európában pedig föleg az önkényuralmi rendszereket felváltó radikális változások, a II. világháborút követő fejlödés demokratikus és emberi jogi igényei, a faji, nemzeti, vallási, politikai diszkrimináció nemzetközi jogi és alkotmányi tilalma érvényesülésének nehézségei, a föderativ szerkezetü vagy nemzeti, illetve regionális autonómiákkal rendelkezö államok sajátos belső egyensúlyi problémái, a parlamenti többség és a kisebbségi ellenzék közötti viszony fair play szabályai valóra váltásának visszásságai, és az új tartalmú alkotmányosság iránti egyéni, közösségi és társadalmi igények fokozódása járultak hozzá és táplálják az alkotmánybíróság intézményének létrehozását és növekvő szerepét (Beyme 1995; Favoreu 1995). Néhány európai országban az is érzékelhetö, hogy az alkotmánybíráskodás az uniós jog, valamint a luxemburgi és a strasbourgi ítélkezés bizonyos túlzásaival szembeni nemzeti ellensúlyozás szerepét is vállalja.

Az alkotmány és az alkotmányosság felértékelődésének körvonalazott folyamatát a fejlett országok közjogi szakirodalmában egyre terjedő szakkifejezéssel a jogállam és a jogrendszer alkotmányosodásának nevezik (Ádám 1998a). A jogállamiság új fejlődési szakaszát jellemzö alkotmányosodás egyaránt megnyilvánul 
az alaptörvény tartalmi gazdagodásában, a jogrendszert alkotó jogágazatok eróteljes alkotmányi meghatározottságában, az államszervezet, a törvényalkotás alkotmányi kötoöttségében és az alkotmányi rendelkezések alkotmánybírósági védelmében. Az alkotmányi értékeknek tanulmányom következỏ fejezetében elvégzett áttekintése arról is meggyőzhet bárkit, hogy az alkotmányos jogállamnak szükségképpen demokratikus jellegünek kell lennie, és egyben szociális érzékenységet kell tanúsítania.

d) Sokan megállapították már, hogy a joguralom, vagyis a rule of law koncepciója, az alkotmányosság amerikai modellje és a Rechtsstaat német fogalma nem fedik maradéktalanul egymást. A jogállamiság német illetve európai koncepciója a rule of law-hoz viszonyítva egyrészt részletesebb alkotmányi és törvényi szabályozásban testesül meg, másrészt ennek következtében aprólékosabb jogi szövegezéshez köti a jogalkotó, a jogalkalmazó és a végrehajtó szervek müködését, valamint a polgárok magatartását.

e) Az alkotmányos jogállamnak van elmélete, vagy ha úgy tetszik, van ideológiája, sőt vannak eszméi és eszményei is. Eltérően azonban a történelem számos nagy teóriájától, filozófiai koncepciójától, az alkotmányos jogállam elmélete sem magát, sem a vizsgált normákat, sem azok gyakorlatát nem tekinti, és nem is tekintheti lezártnak. Nem léphet fel azzal az igénnyel, hogy a jogállam elérkezett fejlödésének csúcsára. A platóni örök, tökéletes és változatlan metafizikai ideákkal szemben az alkotmányos jogállam eszméit és eszményeit, normaanyagát és gyakorlatát folytonosan változó és tökéletesítendỏ értékekként kell kezelnünk. Ennek a plurális értékrendszernek kereteit és lényeges közös összetevỏit az alkotmányi értékek testesítik meg.

\section{Értékelméletek és alkotmányi értékek}

1) Az értékek az emberi egyéni vagy közösségi értékelés termékei. Az értékelés mérlegelést, becslést, megítélést jelent. A mérlegeléshez, értékeléshez ismérvek és mértékek szükségesek. Az értékelés ezek felhasználásával kưlönbözỏ tárgyak: transzcendenciák, természeti adottságok, emberi célok, alkotások, követelmények, tulajdonságok, megnyilvánulások minösítését és arányositását jelenti, amely az ertekeit targykörök rangsorolásához vezet.

A vallási, az erkölcsi, a mủvészeti, a jogi és az anyagi értékck sajátosságaival az ágazati értéktanok foglalkoznak. Az általános értéktan müvelöi közül sokan az egyetlen, végsỏ érték és legföbb értékmérő fogalmát kutatták. Így születtek meg az élvezeteket első helyre állító hedonista, az emberi boldogságot preferáló eudémonista, a hasznosságot respektáló utilitarista, a fejlődést vagy a tökéletesedést legföbb értéknek nyilvánító evolucionista, perfekcionista értékelméletek. Az említett értéktanok nagyrészt az általuk képviselt értékfelfogás helyességének kizárólagosságát hangsúlyozzák, és nem ismerik el az értékek koronkénti, tájegységenkénti, társadalmi rétegenkénti változatosságát. A modern értéktani felfogások 
ezzel szemben az értékelési ismérvek és az értékek sokféleségét és változékonyságát hangsúlyozzák. Az egyéni és a közösségi értékké váláshoz természetesen mellőzhetetlen, hogy az értékfelfogás az értékelö alany illetve alanyok szemléletét, lelkiismeretét, felelősségérzetét áthassa, és ezen keresztül állásfoglalásait, tevékenységét, viselkedését tartósan meghatározza.

Rendkívül fontos az a felismerés, hogy valamely érték realitását és súlyát nemcsak a benne megtestesült, illetve belöle fakadó elöny érzékelteti, hanem az érték ellentéteként vagy hiányaként szereplö hátrány, veszély mérete is. Az érték tehát az értékelt tárgynak ember által tulajdonitott lényeges minösége. Az érték által kiváltott emberi elismerés, tisztelet, helyeslés, az értékkel való azonosulás azt is kifejezi, hogy az értéktételezés, az érték léte és fennmaradása szükségképpen magában foglal bizonyos kötelező, késztető hatást az értéket elismerők irányában akkor is, ha az értékhordozó nem tekinthetö jellegzetes normának. Hangsúlyozandó azonban, hogy a nem anyagi értékek jelentös hányadának értékhordozója vallási, erkölcsi, jogi vagy egyéb társadalmi norma. Ez a körülmény természetes következménye annak, hogy az emberi közösségek törekszenek arra, hogy jelentős transzcendentális és evilági értékfelfogásaikat normatívákba foglalják, és ezáltal kötelezö vallási, erkölcsi, állami, nemzeti és nemzetközi tiszteletben, követésben és oltalomban részesítsék.

Az emberi, illetve a társadalmi normák léte, tartalma, hierarchiája - tudatosan vagy anélkül - tehát rendszerint az emberi értéktételezésekhez és értékekhez kapcsolódnak. A jogi normákba foglalt értékeknek, a jogrendszert alkotó jogi normáknak azonban - legalábbis elvileg és logikailag - egymáshoz kapcsolódó, egymásra épưlö, ellentmondásmentes értékrendszert kell alkotniuk. A nemzetközi egyezményekben rögzített jelentös jogelvek, tilalmak, alapjogok és kötelességek, az országok különbözö tárgyú és terjedelmü integrációs törekvései és jogharmonizációs munkálatai pedig a jogrendszerekbe foglalt és általuk védett értékek egységesülését is szolgálják.

Korszakunk lényeges változásai, különösen a bipoláris hatalmi struktúra megszünése, a globalizációs és differenciálódási folyamatok egyidejű erősödése, az információs világtársadalom kialakulása, az olyan súlyos válságtünetek, mint a vallási és etnikai gyưlöletböl fakadó kegyetlenkedések, az ortodox-fundamentalista közösségek elkeseredett és kíméletlen fellépései, a munkanélküliség, az infláció, az eladósodás, a szegényedés, a szervezett és egyéb bünözés, különösen a terrorizmus, a korrupció, a prostitúció, a kibernetikai bünözés, a biogenetikai visszaélések, a kábítószer-fogyasztás és egyéb szenvedélybetegségek terjedése, a súlyos és gyógyíthatatlan epidémiák pandémiává válása, az élövilág és a természet más összetevöinek pusztulása, a szörnyü kataklizmák, a gyakori közlekedési akcidenciák és a fenyegető müszaki katasztrófák, nem különben az emberek közötti figyelmesség, előzékenység, szavahihetőség, türelem, korrektség és a bizalom hiánya vagy lazulása, továbbá számos egyéb hátrányos jelenség sokakban reményvesztést váltanak ki. Tagadhatatlan, hogy korszakunkban is, mint a történelemben 
annyiszor, az emberiség értékválsággal küszködik. A gondolkodó és felelös lelkuletủ embereket pedig új értékek keresésére és meghatározására, az értékek újrarendezésére, mindezek alapján esetleg átfogó paradigmaváltásra serkentik korszakunk válságtünetei. A paradigmaváltást megtestesítö értékrendezés egyaránt magában foglalja a hagyományos és bevált értékek megtartását, elavult értékek szelektálását, új értékek elötérbe állítását, az értékrangsorolás új ismérveinek és módszereinek kialakítását.

A problémák, az útkeresések ismeretében valószinüsíthetjuk, hogy az egyre többek által szorgalmazott érték-újrarendezés vagy paradigmaváltás sarkalatos teendői kőzé az ember, az élővilág, a természeti környezet túlélésének, fennmaradásának biztosítására, a fenntartható fejlödés lehetővé tételére, bizonyos eszmei javak, az életminöség közösségi, kulturális, erkőlcsi, testi és lelki egészségi, szociális és közbiztonsági összetevőinek fejlesztésére irányuló értéktételezések tartoznak. Az ilyen holisztikus szemlélet csak olyan értékfelfogásból indulhat ki, amely az embert, az emberiséget, az eszmei értékeket, a természeti és mủvi környezetet szerves egységben szemléli, szolgálja és óvja.

2) Az alkotmányban foglalt értékek alaptörvényi szintủ és erejủ normatív jogi objektivációk, olyan értékkategóriák, amelyek alkotmányi értékminöségưket az alkotmányozó hatalomtól nyerik (Ádám 1998c). Ezek állami, társadalmi és egyéni elismerésének és tiszteletének kötelességét az alkotmányozó írja elő. Az alkotmányban meghatározott értékek a jogi normatív értékek élén helyezkednek el. Ebböl az kővetkezik, hogy az ország valamennyi jogalkotó és jogalkalmazó szerve, minden állampolgár, az ország területén tartózkodó valamennyi természetes és jogi személy, emberi közösség köteles ezeket tiszteletben tartani. Elönyös természetesen, ha az alkotmányi értékeket nemcsak kötelezö tisztelet ơvezi, hanem ha ezek az értékek széles körben a politikusok, a köztisztviselök, a közalkalmazottak és más állampolgárok tudatát, szemléletét és magatartását az elfogadás, az egyetértés, a meggyőződés erejével hatják át. Az internálódás, az interiorizálódás foka az alkotmányi normatív értékek tekintetében is a társadalmi, kőzösségi és egyéni értékekké válás szintjét jelzi. Méltán állíthatjuk, hogy a fejlett alkotmányi értékek társadalmi elfogadottságának kiterjedtsége és mértéke az alkotmányos intézményrendszer legitimációját, az alkotmányos szemlélet, az alkotmányosság, a közjogi kultúra szinvonalát is kifejezi.

Az alkotmányos jogállam korszerü alkotmánya olyan értékek alaptörvényi rangra emelt, tehát legnagyobb normatív erővel felruházott gyüjteménye, amelyek értékességét az emberiség közös történelmi tapasztalatai támasztják alá. Ezeknek az értékeknek feltárásában, kimunkálásában és elismerésében egyaránt részt vettek a hellén politikai és etikai kultúra protagonistái, a római jog és a természetjog elveinek megfogalmazói, a zsidó-keresztény vallások teológusai, a liberális, a konzervatív, a szocialisztikus szellemi, ideológiai, politikai koncepciók teoretikusai és élharcosai. A háborúk borzalmainak és az önkényuralmi rendszerek kegyetlenkedéseinek tapasztalatai alapján normatív erejủ meghatározó szerepet ezek megállapí- 
tásában mégis a nemzetközi egyưttmüködéssel kimunkált olyan nemzetközi okmányok töltöttek és töltenek be, mint az ENSZ alapokmánya, az Emberi Jogok Egyetemes Nyilatkozata, valamint a jelentös alapelveket, tilalmakat és alapjogokat meghatározó más nemzetközi dokumentumok. A vallási, nemzeti, etnikai, politikai és egyéb érdekközösségek, a nemzet, a társadalom, az emberiség olyan klenódiumai ezek, amelyek méltán tekinthetők a világnézeti, kulturális, politikai irányzatok és a gazdasági koncepciók többsége által elfogadható, tiszteletben tartható, közös értékminimumnak. Az alkotmányos jogállam alkotmányi értékeit ezért a korszerũ értékpluralitás közös nevezöjének, nélkülözhetetlen közös kincsének minösíthetjük. A részben nemzeti, másrészt egyre kiterjedtebb méretekben egyetemesedö alkotmányi értékek mellözhetetlen szerepre hivatottak, és képesek is az emberi csoportok, a társadalom, a nemzet és a nemzetközi kőzösségek kohéziójának, integritásának és szerencsés esetben konkordáns együttműködésének elömozdítására. $\mathrm{E}$ lényeges tartalmi sajátossághoz azonban vitathatatlan kötelező erő is kapcsolódik. Itt jegyzem meg, hogy azokban az országokban - így Magyarországon is -, amelyekben következetesen megvalósult az állam és az egyházak különválasztása, az alkotmány és az állam világnézetileg semleges abban az értelemben, hogy nem emel az állami ideológia rangjára egyetlen vallási, ateista vagy materialista világnézetet sem. Ez a világnézeti semlegesség azonban nem jelent közömbösséget az alkotmánnyal nem ellentétes, nyilvántartott vallások, egyházak és vallási közösségek tekintetében. Az alkotmányos jogállam lelkiismereti és vallásszabadság jegyében biztosítja az ilyen vallások, egyházak, valamint az egyéb világnézetek egyenjogú pluralitását. Az alkotmány és az állam világnézeti semlegessége tehát korántsem jelent értéksemlegességet. Az alkotmányban biztosított lelkiismereti és vallásszabadság magában foglalja a vallásos világnézetek és a világnézeti pluralitás értékes voltának elismerését, sőt intézményes állami támogatását is.

Az alkotmányi rendelkezések értéke olyan normatartalmakban testesül meg, amelyeknek értékes voltát a rendeltetés, az elérni szándékolt hatás, a célzott következmény és a tényleges eredmény elönyös, kedvezö volta igazolja. Az alaptörvényben foglalt, illetve foglalható normatív értékcsoportok között jellegük, tartalmuk és rendeltetésúk alapján kiemelkedő szerepre hivatottak az alkotmányi alapelvek, tilalmak, alapjogok, alapkötelességek, az egyéb nevesített alkotmányi értékek valamint az államcélok és az állami kötelességek. Ezekhez az alapvetö rendelkezésekhez kapcsolódnak az állami szervek szervezeti felépítésére, feladatkörére, hatáskörére és eljárási rendjére vonatkozó alkotmányi elöírások.

a) A felsorolt alkotmányi értékcsoportok közül az alkotmányi alapelvek körében az államhatalmi ágak elválasztása, mint alkotmányi alapelv a hatalom megosztottságát, a hatalmi központok elkülönülését és kölcsönös ellenörzését, egyensúlyozását, az önkényes hatalomgyakorlás elkerülését szolgálja. A bírói fuggetlenség elvének alkalmazásával mükődhet a kủlső hatalmi tényezők befolyásától mentes önálló, törvényes és pártatlan igazságszolgáltatás. A népesség egészét érintö értékes alkotmányi alapelvként szerepelhet a népi hatalom képviseleti és 
közvetlen gyakorlásának elve. Indokolt alkotmányi alapelvi rangra emelni a politikai pártok, a közjogi autonómiák, az érdekszervezetek és a különböző civil társulások demokratikus mükődésének követelményét is. Az állam egészét érinti a jogállam alkotmányos, demokratikus és szociális jellegének, az állami szervek együttmükődési, kölcsönös segélynyújtási kötelességének valamint az állami tevékenység átláthatóságának elve. Az alkotmányi értékeknek ugyancsak ebbe a csoportjába sorolhatjuk az egyházak és az állam elválasztásának, az állam világnézeti semlegességének alapelvét. A jogrendszer egészét érintő alapelvekként lehet rögzíteni a jogbiztonság elvét és a jogforrások hierarchikus viszonyából fakadó követelményt.

A jogágazati alapelvek közül a korszerü alkotmány nem nélkülözheti az alapjog tartalmú ismert büntetőjogi és büntetỏ eljárási alapelveket, közöttük első helyen a szabálysértési és fegyelmi felelösségre is kiterjesztendő „nullum crimen sine lege, nulla poena sine lege" elvét. Részben jogrendszeri, részben polgári jogi alapelvként lehet megállapítani a szabad verseny tisztességes jellegének követelményét. Elo̊nyös lenne, ha az új alkotmányban alapelvként megerösítést nyerne az állami és önkormányzati alkalmazottak sajátos alkotmányhüségének követelménye, továbbá a polgári jogok és kötelességek gyakorlása illetve teljesítése során a felek jóhiszemüségének és tisztességének, valamint a jogok rendeltetésszerú gyakorlásának, a tulajdon ésszerü, a közösségi érdekeket is tiszteletben tartó használatának elve. Témánk szempontjából külön is kiemelem a hazai közigazgatás-tudomány müvelőinek azokat a nagyrészt egybehangzó ajánlásait, amelyek szerint az új alkotmányban a jelenleginél részletesebben és korszerübb tartalommal kellene rendelkezni a közszolgálatról, a köztisztviselókről, a közigazgatás alkotmányi alapelveiről, szervezetrendszeréről és a közigazgatáshoz kapcsolódó társadalmi-szakmai egyeztető mechanizmusról.

b) Az alkotmányi értékek körében jelentős csoportot alkotnak az alaptörvénybe foglalt tilalmak. A tilalom fogalmából önként következik, hogy olyan kötelezést tartalmaz, amely valaminek a mellózésére, elkerưlésére, valamitól való tartózkodásra irányul. Jóllehet az állam, mint az alapjogok elsődleges kötelezettje az alapjogok védelmére, törvényi szabályozására és érvényesülésẻnek intézményes biztositására kötelezett, vele szemben Magyarországon kifejezetten az alkotmány állapítja meg azt az általános tilalmat, hogy alapvető jog lényeges tartalmát törvény - és természetesen más jogszabály - nem korlátozhatja. Az alapjogok harmadik személyek irányában megnyilvánuló hatása egyben minden kủlsỏ jogalanyt kötelez arra, hogy tiszteletben tartsa mások jogait és tiltja mások alapjogai érvényesülésének jogtalan zavarását.

Az alkotmányi tilalmak címzettjeikẻnt esetenként az állam egésze, meghatározott állami szervek, állampolgárok, közösségek, politikai és civil szervezetek stb. szerepelhetnek. Az államra és a közhatalmi (tehát az állami és az önkormányzati) szervekre vonatkozó tilalmak rendszerint az alkotmányban rögzített egyéb értékek (alapelvek, alapjogok stb.) védelmét szolgálják. Az államra háruló tilalmak, mint 
kötelezettségek tiszteletben tartása az érintettek számára igényt, jogosultságot fakasztó hatást gyakorol. Az alkotmányi tilalmak értékes voltát alátámasztó tárgyköröket és a tilalmak értékes következményeit az alábbi példák érzékeltetik. A hatalom erőszakos megszerzése és kizárólagos gyakorlása tilalmának nagy értékủ védett tárgya a demokratikus alkotmányos jogállami intézmények egész rendszere. A nemzeti, faji, vallási, politikai gyülöletre uszítás, az ilyen indíttatású diszkrimináció, ellenségeskedés, erőszak és az agresszió nemzetközi jogilag is elöirt, abszolút tilalma az emberiség ember által okozott eddigi szenvedéseinek legveszélyesebb forrását kívánja kiiktatni, és egyben az egyik legáldásosabb értéket, a köznyugalmat, a békés, kellemes és tartalmas emberi egyuittélést szolgálja. Alig szorul bizonyításra a kínzás, a kegyetlen, embertelen és megalázó büntetés illetve bánásmód, továbbá a hátrányos tartalmú jogszabályok visszaható hatálya, a joggal való visszaélés és a hatáskör-elvonás tilalmának értéket védö szerepe.

c) Az alapjogok értékes volta megvalósulásuk sokrétü védelmi és egyéb elönyös szolgálati szerepében nyilvánul meg. A szabadságjogok többségének az egyén és a kőzösség egyưttes szolgálatán kívul, illetve azzal együtt nélkülözhetetlen a szerepe a változatosság, a sokszínüség és a sokasodás, vagyis a pluralitás és a tömegesedés valamint a versengés érvényesíthetőségében. Gondoljunk kulönösen a kifejezés, a tudomány, a mủvészet, a vallás, az egyesulés, a gyülekezés, a vállalkozás szabadságának értékteremtỏ és a pluralitást, mint értéket szolgáló rendeltetésére. A politikai jogok a demokratikus hatalomgyakorlást, a közérdekú adatok megismerésének alapjoga pedig a kőzhatalmi szervek müködésének átláthatóságát teszi lehetővé. Nem szorul bizonyításra a szociális, kulturális és egészségvédelmi alapjogok előnyöket nyứjtó, tehát értékes szerepe sem.

d) Értékvédelemre hivatottak természetesen az alkotmányban foglalt alapvetö kötelességek is, így kulönösen az alkotmány és a törvények megtartásának, a közterhek viselésében való arányos kőzremükődésnek, a természeti és kulturális értékek, a közegészség, a közerkölcsők védelmének, a szülök nevelési feladatainak valamint az általános és ingyenes tankötelezettség teljesítésének kötelezettsége. A lelkiismereti szabadságot is figyelembe vevő, új tartalmú, differenciált megfogalmazásra szorulnak a honvédelmi kötelességek.

e) Bizonyos elvek, alapjogok, tilalmak és kötelességek, mint normatív értékek alaptörvényi meghatározása mellett a modern alkotmányok gyakran minösítenek meghatározott intézményeket, viszonyokat, megnyilvánulásokat, természeti és mủvi tárgyakat alkotmányosan védendö, úgynevezett egyéb nevesített alkotmányi értékeknek. Ennek alapján ilyen nevesített alkotmányi érték lehet a népek, nemzetek, országok, államok kölcsőnős bizalmán és tiszteletén nyugvó általános béke, a belső társadalmi rétegek, közősségek közötti, valamint ezek és az állam kőzötti érdekegyeztetést és megállapodást célzó együttmüködés, az erőszak-, gyưlölet-, félelem- és nélkulözésmentes élet, a hátrányos helyzetben lévơk, a bajba jutottak iránti társadalmi szolidaritás, a kölcsönös türelem, a haladó emberi, 
nemzeti és etnikai kulturális örökségek, valamint az ország nemzetközi jogilag vagy törvényben védeni rendelt természeti és müvi értékei, továbbá a piacgazdaság, a család, a házasság és az ifjúság. Az is nyilvánvaló, hogy a nemzeti és állami szimbólumokról szóló alkotmányi rendelkezések olyan kiemelkedő értékekhez kapcsolódnak, mint a népfelség és az állami szuverenitás, a nemzeti önazonosság, az államterületi integritás és sérthetetlenség.

A különbözö jellegủ és tartalmú alaptörvényi rendelkezések konzisztenciájánál és koherenciájánál fogva kiinduló bázist és ösztönzést jelenthetnek az ilyen tartalmú alkotmányi megállapítások a jelzett értékkategóriák fennmaradását, érvényesülését, valóra váltását célzó fejlesztő vagy védelmi jellegủ jogszabályalkotás és más állami, társadalmi eröfeszítés számára egyaránt. Fontos támpontul szolgálhatnak ezek az értékek is az alkotmány egyéb rendelkezéseinek értelmezéséhez, a felmerülő alkotmányossági kollíziók elbírálásához.

f) Az alkotmányban rögzített államcélok és az állam alkotmányban megállapított alapvetö kötelességei egyaránt kötik az államot, senkit nem részesítenek azonban kikényszerithetỏ alanyi jogosultságokban. E két kategória jogkövetkezményei tekintetében mégis különbségek állapíthatók meg. Az államcélok szélesebb lehetöséget jelentenek a jogalkotó és végrehajtó szervek számára a megvalósítás eszközeinek, formáinak és módjának megválasztásában. Államcélként szerepel, pl. az alkotmányban az ország határain kívül élỏ magyarokkal való kapcsolat ápolása, helyzetük, sorsuk kedvezö alakulásának elömozditása. Az alkotmányban rögzített állami kötelességek pedig közelebbröl megjelölt és ezért pontosabban számon kérhetỏ feladat-meghatározást foglalnak magukban.

A vázoltak talán meggyőzően érzékeltetik, hogy az alkotmány körvonalazott lényeges összetevői egybekapcsolódó, egységes értékrendszert alkotnak. Bármely alapelv, tilalom, alapjog, alapkötelesség, egyéb nevesített érték, államcél, állami kötelesség stb. alaptörvényi rangra emelése ugyanis azzal a következménnyel jár, hogy az adott kategória közhatalmi, és ennek keretében közigazgatási feladat és felelösség forrásaként szerepel, bizonyos feltételek mellett alkotmánybírósági védelemben részesül, beszámítási pontként szerepel az alkotmányi rendelkezések alkalmazásának esetleges versengésében és a jogszabályok alkotmányosságának elbírálásában. Ezért állapíthatjuk meg ez alkalommal is nyomatékos hangsúllyal, hogy bár az emberi és állampolgári alapjogok az állami feladatoknak és az alkotmánybirósági alkotmányvédelemnek mennyiségi és tartalmi szempontból egyaránt kiemelkedö tárgykörét alkotják, az alkotmánybiráskodás mégsem szükül le, és nem korlátozódhat kizárólag az alapjogi szempontú alkotmányvédelemre. Az Alkotmánybiróságnak Magyarországon is szinoptikus szemlélettel, az alapjogokkal együtt figyelembe kell vennie, és kimunkált arányositási ismérvek alkalmazásával védelemben kell részesítenie az egyéb alkotmányi értékeket is. Így kerülhetö el az alapjogok iniurióvá válása, misztifikálása és mitologizálása. 
3) E rövid áttekintés alapján részben összegezésként, másrészt kiegészitő következtetésekként megállapíthatjuk, hogy az alaptörvényben legfelsőbb normatív erővel megállapított alapértékek körvonalazott rendszere keretet alkot, és egyben a lehetőségek rendkivuul sokirányú és kiterjedt dimenzióit nyitja meg. Megköveteli, hogy az állami szervek, ezek között a közigazgatási szervek, a politikai szervezetek, a köztestületek, az érdekképviseleti és civil szervezetek, a társadalmi közösségek és a polgárok tiszteletben tartsák és kibontakoztassák az alkotmányi alapértékeket, lehetővé teszi, hogy a felsorolt alanyok az alaptörvényi keretek között újabb értékeket fejlesszenek ki. E megállapításból - többek között - az is következik, hogy például az Alkotmánynál alacsonyabb hierarchia fokozatú jogszabályok, elsősorban természetesen a törvények, egyrészt részletezhetik az alkotmányi értékek tartalmát és érvényesullésük módozatait, másrészt az alaptörvényi értékeket nem sértő, új jogi értékeket és ezek által szolgált illetve védett tárgyköröket jelölhetnek meg. Bizonyos alapértékek alkotmányi meghatározása tehát nem zárja le, hanem az egyes értékek tartalmi sajátosságai révén kifejezetten megkönnyíti, sőt serkenti az értékfejlesztő, értékgyarapító aktivitást.

Megfeleló tartalmú alkotmány birtokában az alkotmányos jogállam az általa elismert szabadságjogok és biztositott más lehetőségek ellenére sem tekinthető korlátok nélküli rendszernek. A bemutatott értékek mind az állammal, mind pedig a polgárokkal szemben követelményeket és korlátokat is tartalmaznak. A történelmi tapasztalatok ismeretében az értékek körvonalazott alkotmányi rendszere szigorúan tiltja az alapjogok olyan gyakorlását, amelyböl a védett alapértékeknek közvetlen és súlyos veszélyeztetése vagy sérelme származik. A vizsgált alkotmányi értékek követelményeket támasztanak a versengéssel és a szabadságjogok valamint a politikai jogok által lehetövé tett demokratizmussal szemben is. Az ilyen demokratizmus nem engedi meg, hogy a demokrácia értéksemleges, formális kategória szintjére süllyedjen. A vázolt értékrendszer tehát olyan funkcionáló mechanizmus, amely saját fennmaradását és érvényesulését szolgáló illetve biztosító keretek között az értékek folytonos kutatását, gyüjtését, gyarapitását, tőkéletesítését és rangsorolását teszi lehetővé és egyben szükségessé. Ennek folytán az ilyen értékeket érintó rendszeres viták, versengések egyszerre szolgálják az egyensúlyozást, az ön- és kölcsönös korrekciót, a megegyezést, a konszenzusok felülbírálatát, a rendszeres újraértékelést. Ebben az értelemben a vázolt alkotmányi értékeket tiszteletben tartó társadalmi, politikai és állami rendszer az értékvédelem, értékteremtés, értékrendezés állandó folyamata. Mindehhez mellözhetetlen, hogy az alkotmány minél korszerúbb és gazdagabb tartalommal, minél világosabban határozza meg az alkotmányi értékek jelzett csoportjainak összetevőit. Ehelyuttt is hangsúlyoznom kell ugyanis, hogy chartális alkotmánnyal rendelkezó jogállamban bármely vallási, természetjogi vagy erkölcsi parancs illetve hagyományos jogelv csak akkor válik kőtelező hatást kiváltó és sajátos védelemben részesülö alkotmányi értékké, ha az az alaptörvény rendelkezései között szerepel. 


\section{A jogrétegek szaporodása és a közigazgatás értékkötöttségének kiterjedése}

Korszakunk alkotmányos jogállamának jelentős újszerüsége nyilvánul meg a jogrétegek szaporodásában. A jogi jelenségek vizsgálói a valóság ismeretében már régóta különbséget tettek az elöre rögzített eljárásban, meghatározott szervek által alkotott és megkülönböztető elnevezéssel (törvény, dekrétum, rendelet, statútum stb.) illetett jogi dokumentumokba foglalt országos és helyi írott jog, a bírói kazuisztika által létrejött bíró alkotta jog - más elnevezéssel élö jog illetve esetjog -, valamint a szélesebb társadalmi gyakorlat által követett és a közhatalmi szervek által elismert, sőt esetleg szankcionált szokásjog, továbbá a jogi fogalmakat, kategóriákat, elveket, követelményeket, összefüggéseket és ezek kölcsönhatásait feltáró, kidolgozó és rendszerező - de lege lata vagy de lege ferenda szemléletü - tudományos jogdogmatika, mint jellegzetes jogrétegek között.

Az említett hagyományos jogrétegek valamint a legújabb nemzetközi és hazai jogfejlődés figyelembevételével - megítélésem szerint - megállapithatjuk, hogy mintegy tiz jogréteg egyidejủ, egymás mellett léte és kölcsönös kapcsolata a közigazgatás értékkötöttségére is jelentős hatást gyakorol. A hagyományos jogrétegeken kívül ugyanis napjainkban különösen a következö újabb jogrétegekkel kell számolnunk:

- A nemzetközi szerződéseknek létrejött olyan jelentös újabb csoportja, amelyben a partnerek arra vállalnak kötelezettséget, hogy a kölcsőnősség (reciprocitás) hagyományos nemzetközi elvére tekintet nélkül, vagyis a másik fél kötelességteljesítésétöl függetlenül, belsö normáikba iktatják illetve kihirdetik, és polgáraik valamint a területükön tartózkodó más személyek, mint közvetlenül jogosítottak számára biztosítják az általuk elfogadott nemzetközi dokumentumokban rögzitett alapjogokat, jogelveket, tilalmakat és más rendelkezéseket. Ezáltal az ilyen jellegú és tartalmú nemzetközi jogi normák - a reciprocitáson nyugvó hagyományos államközi normáktól eltéröen - a partnerállamok közös belső jogává válnak, amelynek tiszteletben tartása, érvényesitése hatáskörében eljárva minden állami szervnek, tehát a jogalkotó és a jogalkalmazó szerveknek egyaránt kiemelkedő kötelessége. Közismert ugyanis, hogy az ilyen jellegủ és tartalmú nemzetközi egyezmények rendelkezései, mint közös belső normák - az Alkotmány kivételével - elsőbbséget élveznek a kötelezettséget vállaló partnerállam egyéb jogszabályaival szemben, és többnyire sajátos nemzetközi jogi védelemben is részesülnek.

- A következö, hasonlóan újszerủ és jelentős jogréteget bizonyos nemzetközi, illetve szupranacionális szervek, így különösen az Európai Unió Tanácsa, Bizottsága és Parlamentje által alkotott különbözö (rendelet, irányelv stb.) elnevezésủ, a partnerállamok valamennyi szervét befolyásoló vagy kötelező, és a területükön éló, illetve tartózkodó természetes és jogi személyeket kőzvetlenül jogosító normák alkotják, amelyek ugyancsak az integrációs partnerek kőzös belső jogának minősülnek. 
- Témánk szempontjából figyelmen kívuul nem hagyható, újszerủ jogrétegek harmadik csoportját a Strasbourgban funkcionáló Emberi Jogi Bíróságnak, valamint a Luxemburgban mükődỏ Európai Búróságnak a vonatkozó egyezmények, illetve a megfeleló szupranacionális elöírások tartalmát a partnerállamok valamennyi szervére kőtelező jelleggel végzett értelmezései testesítik meg.

- Ezeken kívull rendkívưl jelentősek természetesen a Magyar Alkotmánybíróságnak az Alkotmányban foglalt alapelveket, tilalmakat, alapjogokat, alapkőtelességeket és egyéb alkotmányi értékeket, illetve más alkotmányi rendelkezéseket kőtelezően értelmező állásfoglalásai is. Az alkotmánybírósági alkotmányértelmezés nem létesíthet olyan elö́rást, nem hozhat létre olyan új normatív objektivációt, amelynek konkrét forrása nem jelölhető meg. Ez a hiteles alkotmányértelmezés ugyanis csak megvilágítja, kibontja, részletezi és ezáltal gazdagítja a tơbbnyire rendkívull rövid, lakonikus alkotmányi rendelkezések értelmét. Mindezzel megkőnnyíti az alkotmányi elöírások követését a jogalkotásban és a jogalkalmazásban.

- Bár nem meghatározó, de nővekvő szerepet tơlt be az az újszerü jogréteg is, amelyet a kőztestületek, kơzintézetek szabályzatai és jogszabályi felhatalmazás alapján tagjaikra és a szolgáltatásaikat igénybe vevőkre vonatkozóan elfogadott egyéb normatív elöirásai alkotnak. Ezeket a részben társadalmi, részben jogi természetủ rendelkezéseket vegyes, átmeneti vagy ún. parajogi normáknak nevezhetjük.

- Ha a közjogi szerződések Magyarországon is intézményesítésre kerülnek, az újszerü jogrétegek hatodik csoportjaként számolhatunk a nem egyetlen esetre, hanem a folytonos vagy ismétlődő viszonyokra vonatkozó, tartós regulációt tartalmazó és ezáltal méltán normatívnak nevezhető közjogi szerződésekkel (Ádám 1995).

- Az országos és helyi írott jog sajátos osszetevő csoportjaként kezelhetjuk végül hazánkban az országos és a helyi népszavazással elfogadott kőtelezö szabályokat és ajánlásokat.

Bár nem minősíthetjưk jogrétegnek, ehelyütt mégis aláhúzom az érdekképviseleti szervezetek, az egyesületek és más civil szervezetek olyan belső szervezeti és mükődésrendi normáinak szaporodását és jelentős szerepét, amelyeket a rájuk vonatkozó jogszabályok keretei kőzőtt, adottságaikhoz igazodó tartalommal ugyan, de kőtelesek megalkotni.

\section{A jogrendszer erkölcsiesedése, mint a közigazgatás értékkötöttségé- nek jelentös üj forrása és megnyilvánulása}

Az etika erkőlcstant, a morál pedig erkölcsöt, illetve az erkőlcsi normák osszességét jelenti. Az erény az erkőlcsi normák tiszteletének készségében és tényleges kơvetésében testesul meg (Heller 1994). Moralitásnak az onmagunk erkölcsi megválasztásából fakadó lelkiismeret szerinti hiteles erkőlcsiség felel meg. A magát immorálisnak választó, rossz ember moralitása ezért szemben áll a széles körben 
elismert erkölccsel. Kifinomult, túlérzékeny lelkiismeret pedig többet diktálhat, mint az általánosan elismert erkölcsi normarendszer (Heller 1996).

Az etika az erkőlcs forrására vagy forrásaira, normáira, az utóbbiak jellegére, rendeltetésére, következményeire, az erkölcsi felelősségre, az erények és a moralitás mibenlétére vonatkozó tudomány. Mind az erkölcs, mind pedig az erkölcstan, tehát a morál és az etika nyugodhat vallásos, hitelvi alapon, és lehet szekularizált jellegú. Mindkét bázisú erkölcs az erkölcsi jó szolgálatára hivatott. Mivel az erkölcsi jó az embernek és az emberi kőzösségnek előnyös, az erkölcsöt, mint az ember szellemét, lelkiismeretét, akaratát, magatartását, felelősségét átható, befolyásoló, serkentő regulatív eszméket értékhordozó, értékkifejező, értékszolgáló kategóriának, rỏviden tehát értéknek minősithetjük. Sokan éppen az erkölcs eszmeiségére és kiemelkedő szerepére tekintettel az erkölcsöt és az erkölcsöst tekintik tulajdonképpeni, esetleg kizárólagos értéknek. Mindezek alapján alig vonható kétségbe az etika, illetve etikák értéktani természete. A többes szám használata egyaránt kifejezi az erkölcsök és a rájuk vonatkozó tanok pluralitását.

Az újabb etikai elméletek problémafelvetései és következtetései közül $K . O$. Apel és J. Habermas (Apel 1992) szekularizált konzekvencionalista erkölcsi koncepciójára utalok. Szerintủk az ideális kommunikációs közösség, ideális beszédhelyzet, nyilvános ckoskodás, nyilvános etikai diskurzus vezethet el a közösségekben, a társadalmi csoportok között, a társadalomban és a nemzetek közötti kapcsolatokban is a korszerú etikai értékek kimunkálásához és elismeréséhez. Az ilyen diskurzusokban a kényszermentesség kényszerének, a türelmetlenség elleni türelmetlenségnek kell uralkodnia. Ez esetben a kimunkált erkőlcsi értékek nem korlátozódhatnak a puszta kötelezésre, a meghatározások nem szorítkozhatnak tehát a teleológiai értéktételezésre. Ezek mellett ugyanis fel kell tárni az erkölcsi normák követésének nem tervezett, vagy kifejezetten elkerülni szándékolt mellékhatásait is. Mindezeket a következményeket az erkőlcsi értékek olyan felelös alakitásának, követésének és formálásának folyamatában remélhetjük elérni, amelyben egymásra épủl és egymásra tekintettel alakul a személyiségi, a kis-, a közép- és a makrokőzösségi erkölcsi értékek kölcsőnősen felelős követése, és a kapcsolódó etikáknak a megfelelő kommunikációs közösségekben folytatott nyilvános diskurzusos müvelése. Úgy vélem, ebbe a folyamatba szervesen illeszkedhet a különbözö szakterületek, élethivatások, a gazdasági és szakmai kamarák etikai kódexeinek, pragmatikáinak elókészitése, elfogadása és alkalmazása is.

Paradoxonnak tekinthető, hogy a szervezett és egyéb bünözés félelmetes szaporodása, a terrorizmus, a korrupció, a prostitúció, az erőszak és kegyetlenkedés, a kábítószer-fogyasztás, a biogenetikai és biomedicinális visszaélések terjedésének időszakában az alkotmány és a jogrendszer erkölcsiesedéséröl beszélhetünk. Pedig az erkőlcsiesedés szilkségességét éppen a jelzett negativ jelenségek támasztják alá. Mivel egyrészt a jellegzetes jogi eszközök nem bizonyulnak a vázolt deliktumok és visszaélések elleni küzdelemben eléggé hatékonynak, egyre több országban észlelhetỏ az a törekvés és eljárás, hogy a különböző állami és nem állami szervek, szak- 
mai és más közösségek szerepükhöz és jellegükhöz igazodva dolgozzák ki és nyilvánítják magukra kötelezőnek speciális erkölcsi normáikat. Ennek ösztönzésére szaporodnak a jóhiszemüségre és tisztességre, a jog rendeltetésszerủ használatára, a joggal való visszaélés tilalmára, a közerkölcsre, a közszolgálatban levök alkotmányhủségére, az ágazati erkölcsi kódexek kidolgozására vonatkozó alkotmányi elöírások. Ezáltal számos erkölcsi követelmény nyer jogi színezetet, a jogi elöírások végrehajtása pedig erkölcsi biztosítékokkal is kiegészül. A történelemben előfordult és jelenleg is tapasztalható erkölcsi válságok jellegzetes ellentmondását találóan fejezi ki Rudolf Jhering ismert következő megállapítása: „az emberiség feljegyzéseket készít magának törvényeiben kiveszö erkölcsi érzékéröl, kivesző értékrendjéröl" (Zlinszky 1998, 182). Alig vonható kétségbe, hogy a jogrendszer erkölcsiesedésének jelzett folyamata a közigazgatás és az igazságszolgáltatás értékvédő szerepét jelentös mértékben alakítja.

A jogrendszer erkölcsiesedésének jelzett és elengedhetetlennek tekinthető alakulásában szinte költőinek hangzik a következö kérdés. Jelentik-e, illetve jelenthetik-e az elmondottak, hogy felesleges lenne, ha a magyar alkotmányos jogállam alaptörvénye megfogalmazna néhány jellegzetes erkölcsi követelményt, és bizonyos vonatkozásban utalna a közerkölcs elvárásaira, egyértelmüen elöirná a közszolgálatban állókkal - tehát a bírákkal, az ügyészekkel, a fegyveres testületek fóállású alkalmazottaival, valamint a tág értelemben vett köztisztviselőkkel, tehát az államigazgatási, az önkormányzati igazgatási tisztviselökkel, a köztestületi és más átruházott hatáskörben közigazgatási funkciót betöltő szervek hivatalnokaival, az állam által fenntartott vagy támogatott közintézmények alkalmazottaival - szemben támasztott ún. alkotmányhüség követelményét. Erre a kérdésre - megitélésem szerint - határozottan azt kell válaszolnunk, hogy az alkotmány ilyen tartalmú kiegészítése nem lenne felesleges, sỏt kifejezetten szükségesnek mondható.

E kategórikus megállapítás alátámasztásaként a következő érveket emlitem meg. Néhány jellegzetes erkölcsi alapelv - mint pl. a jóhiszemüség és tisztesség elve, a közerkölcs tiszteletben tartásának követelménye, a szabad verseny tisztességességének elóírása - alkotmányi rangra emelése azzal a kővetkezménnyel járna, hogy valamennyi állami szerv müködésében követendỏ és az alkotmánybíráskodásban is mérceként alkalmazandó értékekként szerepelnének ezek az erkölcsi elvárások. A közhatalmi munkában és a kőzéletben is megszünne az a napjainkban a legmeghökkentőbb visszaéléseket, visszásságokat esetenként oltalmazó és feloldó érvelés, amely szerint igaz, hogy ezek a megnyilvánulások széles körü megítélés szerint erkölcstelenek, de nem ütköznek jogszabályba, tehát nem jogellenesek.

$\mathrm{Az}$ alkotmányhüség kifejezett kimondása pedig egyrészt azért indokolt, mert a közszolgálatban dolgozók jelentős hányada még nincs tudatában annak, hogy önként vállalt és esküvel megerősített státusa ôt arra kötelezi, hogy hivatali feladatának gyakorlása közben és azon kívül is rá az a jogi és erkölcsi kötelesség hárul, hogy az erkölcsi gondosság különös igényével segítse elő az alkotmányos rend kibontakozá- 
sát, az alkotmányi értékek érvényesülését, és az őt alkalmazó intézmény rendeltetésének betöltését.

Annak alaptörvényi ösztönzése, alkotmányi legitimációja, a megvalósịtás alaptörvényi meghivatkozhatósága és egyben alkotmányossági védelmezhetősége érdekében, hogy a közszolgálat jellegzetes szféráiban, így a köztisztviselők tekintetében is olyan adaptált etikai normák, közigazgatási erkölcsi szabályok kerüljenek kimunkálásra és elfogadásra, amelyeket maguk az érintettek - érdekképviseleti szerveik és alkalmazó intézményeik szervezésében - nyilvános és felelős viták keretében alakítanak ki, meggyőződéssel javaslom, hogy az új magyar alkotmány foglaljon magában erre vonatkozóan is rövid, de világos és egyértelmü felhatalmazást, illetve kötelezést. Ez az indítvány természetesen korántsem jelenti azt, hogy a közigazgatási etikai kódex kifejezett alkotmányi rendelkezés hiányában nem dolgozható ki, nem fogadható el és nem alkalmazható (Ádám 1998b).

Az alkotmányi, az egyéb jogi, ezek között az újszerü jogrétegi, a jogi rangra emelt erkölcsi, valamint a közhatalmilag is tiszteletben tartandó vallási, valláserkölcsi, politikai, társadalmi, egészségügyi, tudományos, kulturális, müvészeti, természeti és épített környezeti stb. értékek szaporodása következtében a közigazgatás értékkötöttsége nagymértékben kiterjed és erősödik. A korszerủ közigazgatásnak a hagyományos és az újszerú értékeket illetve ezek változásait is folytonosan figyelemmel kell kísérnie, sőt az értékek gyarapításában, ápolásában, kezelésében és érvényesítésében sajátos felügyeleti, ellenőrzési, egyéb hatósági, tervezési, szervezési, tájékoztatási, ösztơnző, szankcionáló és más eszközeivel körültekintően közre kell müködnie. Mindezek alapján összegzésként megállapíthatjuk, hogy a közigazgatás értékkötöttsége az alkotmányos jogállamban rendkívül széleskörü, erőteljes, differenciált és folytonosan változik.

\section{Irodalom}

Apel, K.O. (1992) Két erkölcsfilozófiai tanulmány. Budapest, Áron Kiadó.

Ádám A. (1995) A kơztestuletek és a kőzjogi szerződések a posztmodern társadalom és állam kapcsolataiban. - Acta Humana. 21. 16-30. 0.

Ádám A. (1997) Az alkotmányos jogállam fỏbb jellemzői. - Jogtudományi Közlöny. 2. 74-77. o.

Ádám A. (1998a) A jogrendszer alkotmányosodása és erkolcsiesedése. - Jogtudományi Közlöny. 10. 351-359. 0.

Ádám A. (1998b) A kơzszolgálati erkơlcs alkotmányi és egyéb forrásairól. - Magyar Közigazgatás. 5. 257-264. 0.

Ádám A. (1998c) Alkotmányi értékek és alkotmánybíráskodás. Budapest, Osiris Kiadó.

Bán T.-Konyves Tóth P. (1997) A szabályozó felügyeleti hatóság alkotmányos feltételeinek megteremtéséről. - Jogtudományi Közlömy. 4. 165-171. o.

Beyme, von K. (1995) Alkotmánybíráskodás. Alkotmánybiráskodás, alkotmányértelmezés. - Paczolay P. (szerk.), Budapest, ELTE Állami- és Jogtudományi Kar Tempus „Összehasonlitó Jogi Kultúrák” projektumának kiadványai. 117-127. o.

Cappeletti, M.-Cohen, W. (1995) Az alkotmánybíráskodás tơrténete és jelenkori elterjedése. Alkotmánybirảskodás, alkotmányértelmezés. - Paczolay P. (szerk.), Budapest, ELTE Állami- és Jogtudományi Kar Tempus „Összehasonlító Jogi Kultúrák" projektumának kiadványai. 42-52. o.

Favoreu, L. (1995) Az alkotmánybíróságok. Alkotmámybiráskodàs, alkotmányértelmezés. - Paczolay P. (szerk.), Budapest, ELTE Állami- és Jogtudományi Kar Tempus "Összehasonlító Jogi Kultúrák" projektumának kiadványai. 53-116. o. 
Ficzere, L. (1996a) A kormányzati döntések elökészitésének, végrehajtásának és ellenörzésének kérdései. $A$ közigazgatós és ellenörzése. - Fogarasi J. (szerk.), Budapest, Magyar Közigazgatási Kamara-Unió. 47-54. 0 .

Ficzere L. (1996b) Alkotmány és közigazgatás. A közigazgatás korszerüsitése. - Fogarasi J. (szerk.), Buda-pest, Magyar Közigazgatási Kamara-Unió. Budapest, 9-25. o.

Heller Â. (1994) Altalános etika. Budapest, Cserépfalvi.

Heller Á. (1996) Morálfilozófia. Budapest, Cserépfalvi.

Lỏrincz L. (1994) A közigazgatás hazai fejlödésének fö irányai. - Magyar Tudomány. 11. 1313-1318. 0.

Mcloskey, R.G. (1995) Az amerikai legfelsỏbb bíróság. Alkotmánybiráskodás, alkotmányértelmezés. Paczolay P. (szerk.), Budapest, ELTE Állami- és Jogtudományi Kar Tempus „Összehasonító Jogi Kultúrák" projektumának kiadványai. 35-41. o.

Verebélyi I. (1996) A kormányzás és a közigazgatás reformjának tervezete. - Magyar Közigazgatás. 4. 193-229. 0.

Zlinszky J. (1998) Keresztény erkölcs és jogászi etika. Budapest, Szent István Társulat.

\title{
THE INFLUENCE OF VALUES ON PUBLIC ADMINISTRATION IN A CONSTITUTIONAL STATE
}

\begin{abstract}
ANTAL ÁDÁM
Due to the increasing of the constitutional and other legal values (like the moral values put on legal status and religious, ethicoreligious, political, social, health, scientific, cultural, artistic, natural and built environmental values honoured by state) the influence of values on public administration is extending and become stronger in a large measure. Modern public administration has to watch continuously the traditional and recent values and their changes. It has to take considerately an contribute part in the enlargement, caring, treatment and enforcement of values with its specific tools of supervision, control, other authority, planning, organisation, information, encourage and penalty. To summarise all of that the influence of values on public administration in a constitutional state is extraordinarily large, powerful, different and continuously changing.
\end{abstract}

